Disclosure of Interests: Laure Gossec Consultant of: AbbVie, Amgen, Boehringer Ingelheim, Bristol-Myers Squibb, Celgene, Eli Lilly, Gilead, Janssen, Novartis, Pfizer, and UCB, Grant/research support from: Amgen, Galapagos, Janssen, Lilly, Pfizer, Sandoz, Sanofi, Laura C Coates Speakers bureau: AbbVie, Amgen, Biogen, Celgene, Gilead, Eli Lilly, Janssen, Medac, Novartis, Pfizer, and UCB, Consultant of: AbbVie, Amgen, Boehringer Ingelheim, Bristol-Myers Squibb, Celgene, Eli Lilly, Gilead, Janssen, Novartis, Pfizer, and UCB, Grant/research support from: AbbVie, Amgen, Celgene, Eli Lilly, Pfizer, and Novartis, Alexis Ogdie Consultant of: Abbvie, Amgen, BMS, Celgene, Corrona, Gilead, Janssen, Lilly, Novartis, Pfizer, UCB; Grants: Pfizer to Penn, Novartis to Penn, Amgen to Forward/NDB; Royalties: Novartis to husband, Philip J Mease Consultant of: AbbVie, Amgen, Boehringer Ingelheim, Bristol Myers Squibb, Eli Lilly, Galapagos, Gilead, GlaxoSmithKline, Janssen, Novartis, Pfizer, SUN Pharma, UCB, Grant/research support from: AbbVie, Amgen, Boehringer Ingelheim, Bristol Myers Squibb, Eli Lilly, Galapagos, Gilead, GlaxoSmithKline, Janssen, Novartis, Pfizer, SUN Pharma, UCB, Thomas Lehman Shareholder of: Bristol Myers Squibb, Employee of: Bristol Myers Squibb, Miroslawa Nowak Shareholder of: Bristol Myers Squibb, Employee of: Bristol Myers Squibb, Lan Wei Shareholder of: Bristol Myers Squibb, Employee of: Bristol Myers Squibb, June Ye Shareholder of: Bristol Myers Squibb, Employee of: Bristol Myers Squibb, Jiyoon Choi Shareholder of: Bristol Myers Squibb, Employee of: Bristol Myers Squibb, Joe Zhuo Shareholder of: Bristol Myers Squibb, Employee of: Bristol Myers Squibb, Brandon Becker Shareholder of: Bristol Myers Squibb, Employee of: Bristol Myers Squibb.

DOI: 10.1136/annrheumdis-2021-eular.2709

\section{AB0561 DISEASE DURATION AND HLA-B27 POSITIVITY ALTER LONGTERM RETENTION RATE OF CERTOLIZUMAB PEGOL IN PATIENTS WITH PSORIATIC ARTHRITIS}

S. S. Koca ${ }^{1}$, Y. Pehlivan ${ }^{2}$, S. Akar ${ }^{3}$, S. Şenel ${ }^{4}$, H. Karadeniz ${ }^{5}$, O. Sosyal ${ }^{6}$, A. Yazici ${ }^{7}$, S. Yılmaz ${ }^{8}$, R. Piskin Sagir ${ }^{1}$, N. Inanc ${ }^{9}$, A. Karatas ${ }^{1}$, G. Yildirim Cetin $^{10}$, F. Onen ${ }^{11}$ on behalf of TURKBIO Study Group. ${ }^{1}$ Firat University School of Medicine, Department of Rheumatology, Elazig, Turkey; ${ }^{2}$ Uludağ University, School of Medicine, Department of Rheumatology, Bursa, Turkey; ${ }^{3}$ Katip Çelebi University, School of Medicine, Department of Rheumatology, Izmir, Turkey; ${ }^{4}$ Erciyes University School of Medicine, Department of Rheumatology, Kayseri, Turkey; ${ }^{5}$ Gazi University School of Medicine, Department of Rheumatology, Ankara, Turkey; ${ }^{6}$ Celal Bayar University School of Medicine, Department of Rheumatology, Manisa, Turkey; ${ }^{7}$ Kocaeli University School of MEdicine, Department of Rheumatology, Kocaeli, Turkey; ${ }^{8}$ Selcuk University School of Medicine, Department of Rheumatology, Konya, Turkey; ${ }^{9}$ Marmara University School of Medicine, Department of Rheumatology, Istanbul, Turkey; ${ }^{10}$ Kahramanmaraş Sutçu Imam University School of Medicine, Department of Rheumatology, Kahramanmaras, Turkey; ${ }^{11} 9$ Eylul University School of Medicine, Department of Rheumatology, Izmir, Turkey

Background: Several factors such as effectiveness, safety and compliance affect the drug survival in chronic disorders. Physicians take care of longterm retention rate and responses for discontinuation of candidate drug. Identification of predictors of clinical response to certolizumab-pegol (CZP) may aid the decision-making process for treating patients psoriatic arthritis (PsA).

Objectives: The purpose of this study to assess the drug survival of certolizumab pegol (CZP) in patients with PsA and to identify the predictors and reasons for discontinuation.

Methods: Data on patient characteristics, demographics, diagnosis, disease duration, treatment and outcomes have been collected since 2011 in Turkish Biologic (TURKBIO) Registry. By the end of December 2020, 68 PsA patients received CZP and were included. Kaplan Meier plot was used for drug survival analysis. Cox regression analysis was performed to evaluate the predictors associated with drug survival.

Results: During the median 47 months follow-up, 17 patients discontinued the CZP treatment. The reasons for discontinuation were ineffectivity (35.3\%), adverse event $(17.6 \%)$ and pregnancy $(5.9 \%)$. The baseline characteristics of the patients who continued and discontinued CZP were shown in the Table 1. Patients who discontinued CZP had higher mean age and disease duration. HLA-B27 positive patients had lower retention rate while bDMARD naive patients had higher retention rate. At the month 36 , retention rate of CZP was $61.6 \%$ on patients with PsA (Figure 1).

Conclusion: Real life experience from this nationwide TURKBIO registry show that the retention rate of CZP in PSA are lower in older patients and with longer disease duration. Moreover, bDMARD naive patients have higher retention rate.

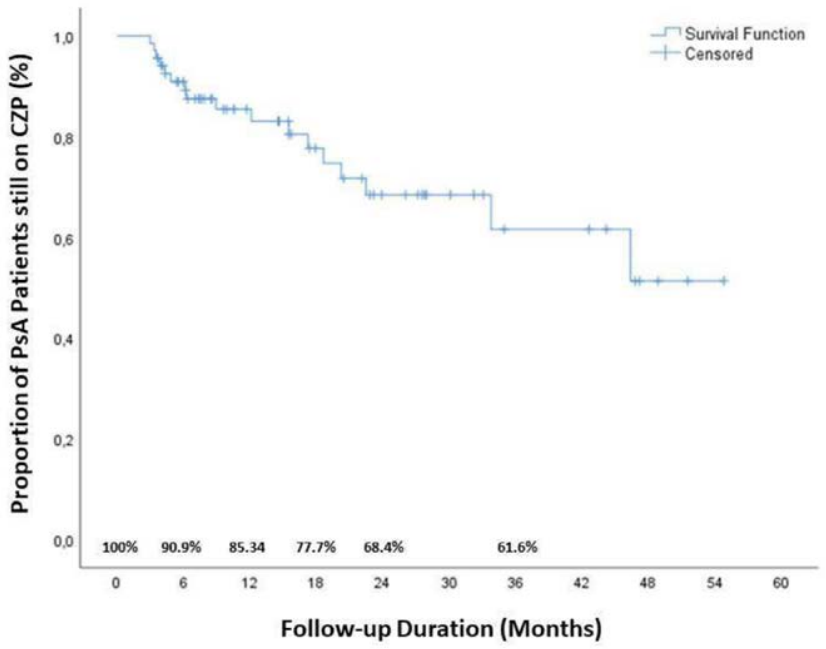

Figure 1. Drug survival of CZP in patients with PsA

Table 1. Baseline characteristics of PsA patients who continue and discontinue CZP

\begin{tabular}{|c|c|c|c|c|}
\hline & $\begin{array}{l}\text { All Patients } \\
(n=68)\end{array}$ & $\begin{array}{l}\text { Continue to CZP } \\
(n=51)\end{array}$ & $\begin{array}{l}\text { Discontinue to } \\
\text { CZP }(n=17)\end{array}$ & p \\
\hline Females, n (\%) & $52(76,5)$ & $37(72,5)$ & $15(88,2)$ & 0,322 \\
\hline Age, years & $44(36-57)$ & $40(35-53)$ & $51(42-60)$ & 0,012 \\
\hline $\begin{array}{l}\text { Disease Duration, } \\
\text { years }\end{array}$ & $9(5-13)$ & $8(5-12)$ & $14(10,5-17)$ & 0,002 \\
\hline $\begin{array}{l}\text { Symptom duration, } \\
\text { years }\end{array}$ & $11(7-16)$ & $10(7-15)$ & $15,5(11,5-20)$ & 0,014 \\
\hline $\begin{array}{l}\text { Order of CZP in } \\
\text { bDMARDs }\end{array}$ & $1(1-2)$ & $1(1-2)$ & $2(1-2)$ & 0,062 \\
\hline HLA-B27, n (\%) & $9(28,1)$ & $3(14,3)$ & $6(54,5)$ & 0,035 \\
\hline $\mathrm{ESR}, \mathrm{mm} / \mathrm{h}$ & $23,5(11-37)$ & $23(9-35)$ & $24(17-52)$ & 0,246 \\
\hline $\begin{array}{l}\text { Swollen Joint } \\
\text { Counts, } n\end{array}$ & $0(0-2)$ & $0(0-2)$ & $1(0-2)$ & 0,480 \\
\hline $\begin{array}{l}\text { Tender Joint } \\
\text { Counts, } \mathbf{n}\end{array}$ & $2(0-4)$ & $1(0-4)$ & $2(1-5)$ & 0,143 \\
\hline CRP, mg/dl & $4(3-13,65)$ & $3,14(3-13)$ & $5(3-19)$ & 0,107 \\
\hline HAQ & $0,63(0,25-1)$ & $0,63(0,25-1)$ & $0,75(0,63-0,94)$ & 0,097 \\
\hline VAS-Physicians & $20(12-31,5)$ & $20(12-26)$ & $30(15-50)$ & 0,074 \\
\hline VAS-Patient Global & $50(27-70)$ & $50(20-70)$ & $61,5(46,5-70)$ & 0,342 \\
\hline VAS-Patient Pain & $53(28-75)$ & $50(20-75)$ & $69(49,5-75)$ & 0,122 \\
\hline DAS-28-CRP & $3,35(2,2-3,9)$ & $2,85(2-3,8)$ & $3,6(2,9-4,4)$ & 0,086 \\
\hline BASFI & $15(8-27)$ & $14(5-26)$ & $23,5(12-30,5)$ & 0,133 \\
\hline BASDAI & $28(16-40)$ & $27,5(14-36)$ & $39(22,5-41,5)$ & 0,060 \\
\hline $\begin{array}{l}\text { ASDAS } \\
\text { DAPSA-28 }\end{array}$ & $\begin{array}{l}2,7(1,9-3,2) \\
15,35(7,2-21,9)\end{array}$ & $\begin{array}{l}2,6(1,9-3,1) \\
14,9(6,1-21,17)\end{array}$ & $\begin{array}{l}3(2,35-3,4) \\
18,9(14,15-29,3)\end{array}$ & $\begin{array}{l}0,122 \\
0,108\end{array}$ \\
\hline
\end{tabular}

Disclosure of Interests: None declared

DOI: 10.1136/annrheumdis-2021-eular.2832

\section{AB0562 POTENTIAL BIOMARKERS OF PERSONALIZED TREATMENT BASED ON CARDIOVASCULAR- RELATED COMORBIDITIES IN PSORIATIC ARTHRITIS}

I. Arias de la Rosa ${ }^{1}$, M. D. López Montilla², C. Román-Rodriguez², I. Gómez García $^{2}$, M. J. Pérez Galán ${ }^{3}$, I. Añón Oñate ${ }^{3}$, M. D. C. Abalos-Aguilera², C. Perez-Sanchez ${ }^{2}$, D. Ruiz' ${ }^{2}$ A. M. Patiño-Trives ${ }^{2}$, M. Luque-Tévar ${ }^{2}$, M. L. Ladehesa Pineda², C. López-Medina², C. Lopez-Pedrera², A. Escudero Contreras ${ }^{2}$, E. Collantes Estevez ${ }^{2}$, N. Barbarroja Puerto ${ }^{1} .{ }^{1}$ Maimonides Institute for Research in Biomedicine of Cordoba (IMIBIC)/Reina Sofia Hospital/University of Cordoba, Medicine Department, Cordoba, Spain; ${ }^{2}$ Maimonides Institute for Research in Biomedicine of Cordoba (IMIBIC)/ Reina Sofia Hospital/University of Cordoba, Rheumatology Department, Cordoba, Spain; ${ }^{3}$ University Hospital of Jaen, Rheumatology Department, Jaen, Spain

Background: Psoriatic Arthritis ( $\mathrm{PsA}$ ) displays increased traditional cardiovascular (CV) risk factors, such as insulin resistance (IR), metabolic syndrome or obesity. Thus, it is an urgent need to treat and manage these 